\title{
Colletotrichum gloeosporioides pe/B Is an Important Virulence Factor in Avocado Fruit-Fungus Interaction
}

\author{
Nir Yakoby, ${ }^{1,2}$ Delila Beno-Moualem, ${ }^{1}$ Noel T. Keen, ${ }^{3}$ Amos Dinoor, ${ }^{2}$ Ophry Pines, ${ }^{4}$ and Dov Prusky ${ }^{1}$ \\ ${ }^{1}$ Department of Postharvest Science of Fresh Produce, Agricultural Research Organization, The Volcani \\ Center, Bet Dagan 50250, Israel; '2Department of Plant Pathology and Microbiology, Hebrew University of \\ Jerusalem, Faculty of Agricultural Food and Environmental Quality Sciences, Rehovot 76100, Israel; \\ ${ }^{3}$ Department of Plant Pathology, University of California, Riverside 92521, U.S.A.; ${ }^{4}$ Department of \\ Molecular Biology, Hebrew University, Medical School, Jerusalem 91120, Israel \\ Submitted 28 December 2000; Accepted 28 March 2001.
}

Colletotrichum gloeosporioides is an important pathogen of tropical and subtropical fruits. The $C$. gloeosporioides pelB gene was disrupted in the fungus via homologous recombination. Three independent isolates, GD-14, GD-23, and GD-29, did not produce or secrete pectate lyase B (PLB) and exhibited $25 \%$ lower pectate lyase (PL) and pectin lyase (PNL) activities and $15 \%$ higher polygalacturonase (PG) activity than the wild type. The PLB mutants exhibited no growth reduction on glucose, $\mathrm{Na}$ polypectate, or pectin as the sole carbon source at $\mathrm{pH} 3.8$ or 6.0 , except for a $15 \%$ reduction on pectin at $\mathrm{pH} 6.0$. When pelB mutants were inoculated onto avocado fruits, however, a 36 to $45 \%$ reduction in estimated decay diameter was observed compared with the two controls, the wild type and undisrupted transformed isolate. In addition, these pelB mutants induced a significantly higher host phenylalanine ammonia lyase activity as well as the antifungal diene, which is indicative of higher host resistance. These results suggest that PLB is an important factor in the attack of $C$. gloeosporioides on avocado fruit, probably as a result of its virulence factor and role in the induction of host defense mechanisms.

Additional keywords: gene knockout, induced resistance, pectolytic enzymes.

Colletotrichum gloeosporioides (teleomorph: Glomerella cingulata), a pathogen of avocado fruits (Prusky 1996), has been found to produce endopolygalacturonase (Prusky et al. 1989; Yakoby et al. 2000b), pectin lyase A (pnlA) (Bowen et al. 1995; Templeton et al. 1994), pectin methyl esterase (Ortega 1996), and pectate lyase B (pelB) (Wattad et al. 1997) during the colonization of infected tissue. Additionally, it was reported that $C$. gloeosporioides $\mathrm{f}$. sp. malvae produces pel-1 and pel-2 (Shih et al. 2000). Such cell wall-degrading enzymes (CWDEs) are considered to play a role in the pathogenesis of bacteria and fungi on their plant hosts (Annis and Goodwin 1997; Collmer and Keen 1986; Ried and Collmer

Corresponding author: D. Prusky; Fax: +972 3968 3622;

E-mail: prusky33@netvision.net.il
1988). Of the several approaches taken to demonstrate their involvement in host pathogenicity such as gene disruption, gene complementation of a deficient mutant, heterologous gene expression, and antisense gene expression, gene disruption has been considered the most direct tool (Bowyer et al. 1995). A significant amount of work has been published on the role of pectolytic enzymes in pathogenesis (Collmer and Keen 1986; Walton 1994). The disruption of single genes, however, frequently led to no discernible phenotype, presumably because several enzymes are secreted during fungal attack (Hamer and Holden 1997). For example, disruption of PNLA from C. gloeosporioides and pectate lyase (PL) from Nectria haematococca did not reduce their virulence (Bowen et al. 1995; Gou et al. 1995). Mutations in five different pel genes of Erwinia chrysanthemi reduced its virulence, but the bacteria were still able to macerate plant tissue (Ried and Collmer 1988), suggesting that a second set of PLs was activated (Kelemu and Collmer 1993). Gene disruption of the two endo- $\beta-1,4-x y l a n a s e s$ from the fungus Magnaporthe grisea did not have any effect on pathogenicity and revealed the secretion of an additional xylanase enzyme (Sheng-Cheng et al. 1997). Disruption of pgx4 encoding the exo-polygalacturonase (PG) of Fusarium oxysporum had no effect on virulence (Garcia-Maceira et al. 2000). Even targeted mutants of Cochliobolus carbonum lacking the two major extracellular PGs retained residual enzyme activity and were as pathogenic as the wild type (Scott-Craig et al. 1998). These reports suggest that other enzymes that share similar or overlapping activities can compensate for the loss of one or more CWDEs. In two cases, however, the disruption of genes encoding constitutively expressed pectinase reduced virulence. The disruption of pecA encoding endo-PG P2c in the saprophytic fungus Aspergillus flavus resulted in decreased cotton boll invasion (Shieh et al. 1997), and disruption of Bcpg1, one of the genes encoding PG, reduced Botrytis cinerea development by 22 to $50 \%$ (ten Have et al. 1998).

To evaluate the importance of $p e l \mathrm{~B}$ to the pathogenic fitness of $C$. gloeosporioides, we used a one-step gene disruption technique that was first used in the yeast Saccharomyces cerevisiae by replacement (Rothstein 1983) or truncation (Shortle et al. 1982) strategies. In this paper, we report the significant effect of pelB disruption on pathogenicity and suggest that 
this reduction may be affected by an induction of resistance mechanisms in the host.

\section{RESULTS}

\section{Gene disruption.}

The pelB clone (GenBank accession no. AF052632) was isolated previously from the genomic library of C. gloeosporioides (Yakoby et al. 2000a). Two strategies to disrupt pelB from $C$. gloeosporioides were attempted. First, a single integration strategy with the use of a $0.62-\mathrm{kb}$ fragment from the pelB clone (downstream from the ATG start codon) together with hygromycin phosphotransferase $(h p h B)$ as the selectable marker failed to generate pelB disrupted mutants (60 hygromycin-resistant colonies were analyzed; data not shown). A homologous recombination strategy was then undertaken with a replacement vector (pGD-4) that contains the $2.13-\mathrm{kb} h p h B$ gene inserted into the $4.1-\mathrm{kb}$ pelB gene clone (Fig. 1A). Following transformation, 110 hygromycinresistant colonies were selected, and isolates were subjected to polymerase chain reaction (PCR) screening. Seventeen isolates were found to lack the PCR 1.12-kb band generated when DNA containing the native pelB is the template (data not shown). Isolates were subjected to Western blot analysis, and three (GD-14, GD-23, and GD-29) did not secrete PLB (Fig. 2). Isolate $\mathrm{Cg}-14$ of the wild-type $C$. gloeosporioides and GD-63 (hygromycin resistant, undisrupted isolate) were used as controls. DNA extracted from five isolates $(\mathrm{Cg}-14$, GD-14, GD-23, GD-29, and GD-63), described above, were subjected to PCR analysis (Fig. 3). Three isolates, GD-14, GD-23, and GD-29, lacked the 1.12-kb band yet had a new 3.33-kb band, as predicted for disrupted mutants (Fig. 3). Isolate GD-63 showed the 1.12-kb band, as in wild-type Cg-14, and an additional $1.7 \mathrm{~kb}$ band. Southern blot hybridization of chromosomal DNA from the various isolates probed with the pelB gene is presented in Figure 1. Isolate GD-63 showed the pelB 7.5-kb pattern as it did in the wild-type Cg-14 (Fig. 1B). In contrast, two bands of 8.13 and $1.5 \mathrm{~kb}$ were detected in the three disrupted mutants (GD-14, GD-23, GD-29), which supports the conclusion that the gene was disrupted via replacement (Fig. 1B). In this regard, for GD-63, the pelB probe detected the $7.5-\mathrm{kb}$ pelB gene and an additional fragment of approximately $12.0 \mathrm{~kb}$, indicating ectopic integration.

\section{Enzymatic activities, growth in vitro.}

The three pelB mutants (GD-14, GD-23 and GD-29), wildtype isolate $\mathrm{Cg}-14$, and the transformed undisrupted isolate GD-63 were grown under pectolytic enzyme-inducing conditions, and the culture media were analyzed for enzymatic activities. Isolates GD-14, GD-23, and GD-29 exhibited, on average, 27 and 25\% lower PL and PNL activities, respectively, whereas PG activity was $15 \%$ higher, on average, than the wild-type $\mathrm{Cg}$-14 (Fig. 4). Isolate GD-63 enzyme-activities did not differ significantly from wild-type $\mathrm{Cg}-14$.

Isolates were grown on different carbon sources in order to check the effect of pelB disruption on their functional interactions with relevant substrates. The in vitro growth rate, estimated as colony diameter, was not affected on glucose or $\mathrm{Na}$ polypectate media at $\mathrm{pH} 3.8$ or 6.0 (Table 1). When isolates were grown in pectin media, at $\mathrm{pH} 6.0$, under conditions in which PLB is secreted into the medium by the fungus
(Yakoby et al. 2000b), a 15\% growth reduction was detected. When isolates were grown in pectin media, at $\mathrm{pH} 3.8$, under conditions in which PLB is not secreted by the fungus (Yakoby et al. 2000b), no growth reduction was found (Table 1).

\section{Pathogenicity on avocado fruits cv. Fuerte.}

Avocado fruits were inoculated with conidia suspensions of the two disrupted mutants (GD-14 and GD-23), an undisrupted transformed isolate (GD-63), and wild-type Cg-14. Pathogenicity was measured daily by decay diameter development. The effect of pelB disruption on the reduction in decay development, on average, of GD-14 and GD-23 was 45 and $36 \%$, respectively, relative to wild-type isolate $\mathrm{Cg}-14$

A
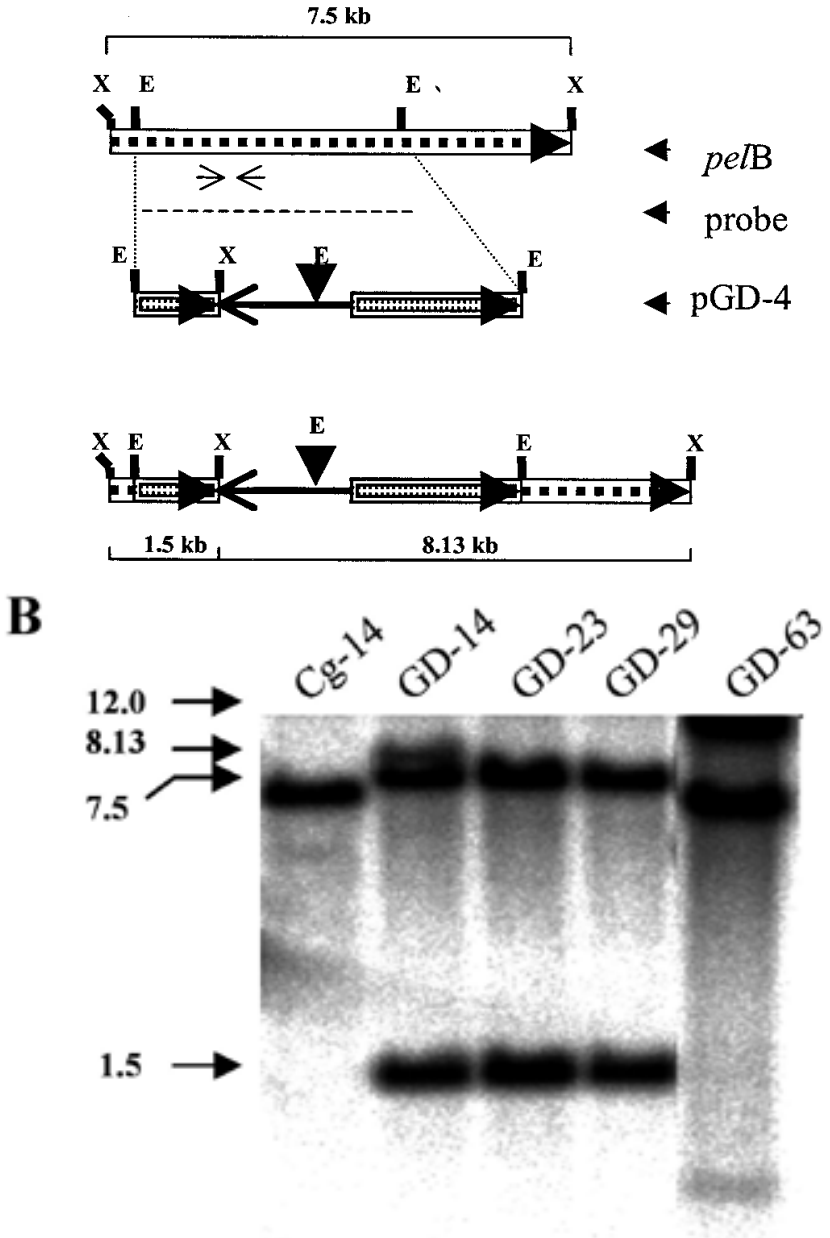

Fig. 1. A, Physical map of pectate lyase B (pelB) genomic locus of Colletotrichum gloeosporioides and gene replacement vector pGD-4. The 7.5-kb pelB locus is indicated by a broken arrow in a clear box. The hygromycin phosphotransferase $(h p h B)$ cassette in the pGD-4 insert is indicated as a solid arrow. The interrupted 4.1-kb locus of pelB in pGD4 is indicated as double-line broken arrows in a box. The fragment used as probe is marked by a stippled bar. Restriction site: E, EcoRI; X, XbaI. Small arrows indicate the position of the polymerase chain reaction primers used for isolate analysis (Fig. 2). B, Southern analyses of pGD-4 replacement mutants of $C$. gloeosporioides isolate $\mathrm{Cg}-14$. DNA of Cg14 ; three pelB mutants GD-14, GD-23, and GD-29; and the hygromycin-resistant, undisrupted isolate GD-63. All isolates were restricted with $X b a \mathrm{I}$ and probed with the 4.1-kb pelB clone. The size of the detected fragments is indicated in kilobases to the left of the blot. 
(Table 2). The undisrupted transformed isolate GD-63, used as a positive control in two independent experiments, did not differ from the wild-type Cg-14 attack on avocado fruits ( $p=$ 0.64 and 0.61).

Phenylalanine ammonia lyase (PAL) is the first enzyme in the resistance-related phenylpropanoid pathway in avocado (Ardi et al. 1998; Prusky et al. 1994), and its activity correlated highly to the increase in epicatechin concentration and, consequently, fruit resistance. Induction of avocado PAL has been used to determine whether disease reduction was effected by an increased resistance of the fruit (Prusky et al. 1994) or solely by PLB loss of function. Avocado pericarp slices inoculated with pelB disrupted mutants showed significantly increased PAL activity over wild-type isolate Cg-14 and the noninoculated control at $24 \mathrm{~h}$ postinoculation (Table $3)$. Pericarp slices inoculated with the undisrupted transformed isolate GD-63, however, did not show increased PAL activity over wild-type $\mathrm{Cg}-14$. Levels of the antifungal diene in avocado fruits inoculated with C. gloeosporioides isolates GD-14 and GD-23 carrying a pelB mutation reached 750 and $740 \mu \mathrm{g}$ per $\mathrm{g}$ fresh weight, respectively, at $48 \mathrm{~h}$ postinoculation, whereas the level of the compound in the pericarp of uninoculated controls and inoculated wild type only was $480 \mu \mathrm{g}$ per $\mathrm{g}$ fresh weight.

\section{DISCUSSION}

The major result observed here was the significant reduction in virulence on avocado fruits by $C$. gloeosporioides car-

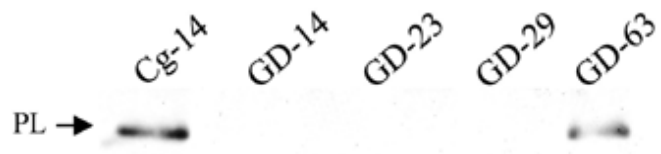

Fig. 2. Western blot analysis of pectate lyase B (PLB) protein-secreted Colletotrichum gloeosporioides. Wild-type isolate Cg-14; the hygromycin-resistant, undisrupted isolate GD-63; and their disrupted mutants GD-14, GD-23, and GD-29 were analyzed. Conidia $\left(1 \times 10^{6}\right)$ were inoculated into $50 \mathrm{ml}$ of pectolytic enzyme-inducing media and shaken at $150 \mathrm{rpm}$, at $22^{\circ} \mathrm{C}$. Culture medium was concentrated, dialyzed, and further concentrated before it was analyzed for the presence of PLB by Western blotting ( $5 \mu \mathrm{g}$ of protein per lane). Arrow indicates position of the PLB $39 \mathrm{kDa}$ product of $C$. gloeosporioides.

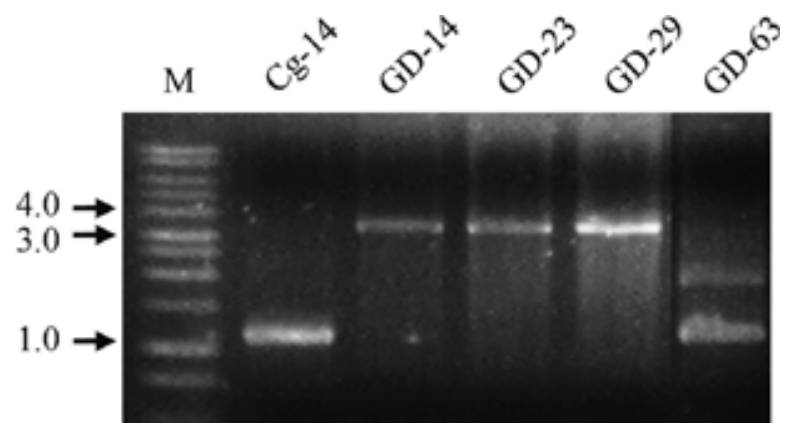

Fig. 3. Polymerase chain reaction (PCR) analysis of pectate lyase $\mathrm{B}$ (pelB) putative disrupted mutants of Colletotrichum gloeosporioides. DNA from putative disrupted $p e l \mathrm{~B}$ isolates was subjected to PCR with two primers corresponding to the internal sequences of the pelB locus (indicated in Figure 3A as two small arrows). Products were compared with wild-type isolate $\mathrm{Cg}-14$ of $C$. gloeosporioides and the hygromycinresistant, undisrupted isolate GD-63. PCR products were run on a $1 \%$ agarose gel and stained with ethidium bromide. rying a pelB mutation (approximately $40 \%$ ). This result was obtained with two independent knockout strains that were rigorously characterized. Control strain GD-63 carrying a nonhomologous insertion was indistinguishable from the wild type in virulence tests and showed no alteration in the production of PL. The pelB knockouts, however, exhibited an approximately $25 \%$ lower PL production in the culture fluids. Furthermore, the knockout strains showed a growth reduction when grown on pectin medium at $\mathrm{pH} 6.0$, where PLB is secreted, but not at $\mathrm{pH} 3.8$, where PLB is not secreted (Yakoby et al. 2000b). The fact that the pelB mutants did not entirely lose PL activity or virulence is consistent with the known presence of additional pel genes in the fungus (Shih et al. 2000). Our gene-disruption results, however, indicate that PLB is an important enzyme-supporting virulence. This conclusion also is supported by previous findings, showing that antibodies raised against PLB reduced symptom development (Wattad et al. 1997), the flavonoid epicatechin in avocado fruits inhibited PL activity and reduced symptom severity (Wattad et al. 1994), and low avocado fruit $\mathrm{pH}$ reduced fungal secretion of PLB as well as disease symptoms (Yakoby et al. 2000b).
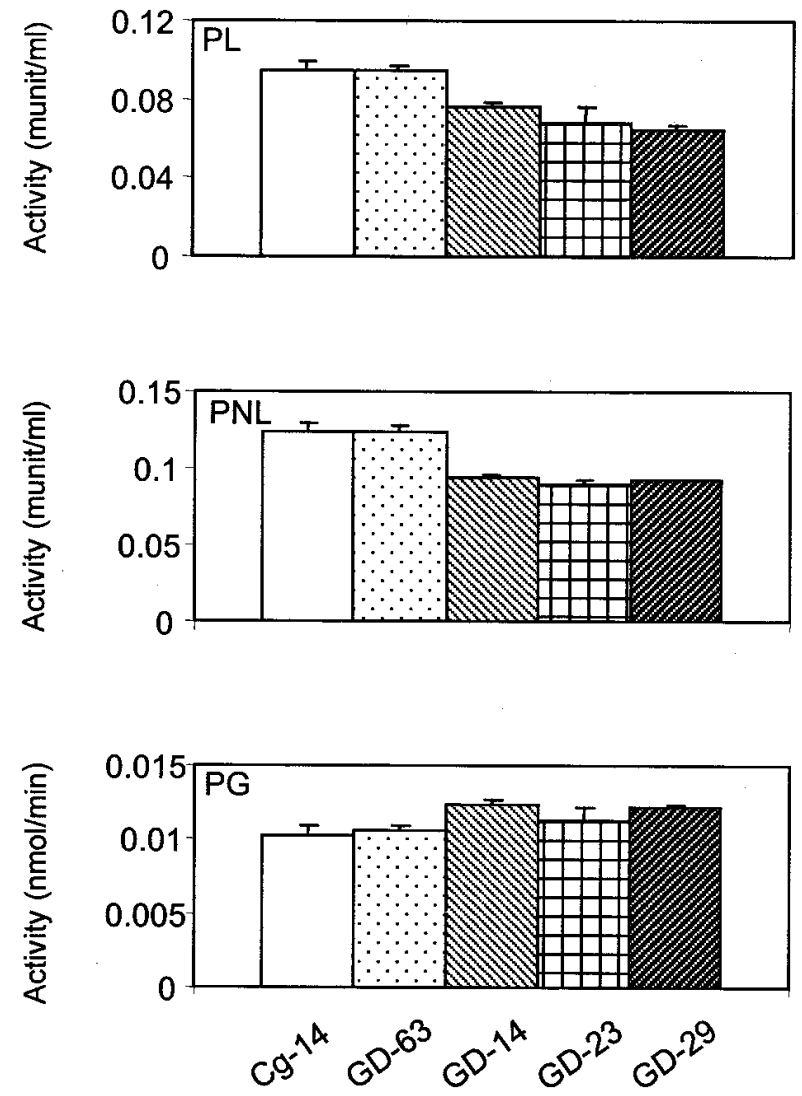

Isolate

Fig. 4. In vitro activities of pectate lyase (PL), pectin lyase (PNL), and polygalacturonase (PG) of Colletotrichum gloeosporioides pectate lyase B (pelB) mutants. Disrupted mutants GD-14, GD-23, wild-type isolate Cg-14 of C. gloeosporioides and the hygromycin-resistant, undisrupted isolate GD-63 were grown in pectolytic enzyme-inducing media (PEIM). Four-day-old PEIM cultures were harvested, and $5 \mu \mathrm{g}$ of the concentrated supernatant was subjected to the enzyme activity assay (units per $\mathrm{ml}$ ). 
Pectic enzymes have been shown to play a role in the attack of plant hosts by tissue-macerating pathogens (Collmer and Keen 1986). Conclusive evidence for their importance, however, has seldom been obtained with fungal pathogens (Walton 1994). Prior to the present work, only two reports have shown evidence for the importance of one single CWDE in pathogenicity: i) the disruption of the constitutive-expressed endoPG gene from $B$. cinerea was found to reduce tomato colonization (ten Have et al. 1998) and ii) the disruption of the constitutive expressed PG of an A. flavus isolate decreased its ability to invade and colonize cotton bolls (Shieh et al. 1997). Most reports on the disruption of a single or combination of CWDEs, however, failed to alter pathogenicity (Bowen et al. 1995; Scott-Craig et al. 1998; Sheng-Cheng et al. 1997). The lack of a single CWDE mutation to have a noticeable change in plant attack is a result of the abundance of gene-encoding enzymes that degrade the polymer barrier of the host (Rogers et al. 2000; Tonukari et al. 2000), which may quench the loss of activity of a single enzyme. Also, a single gene disruption may not be able to reveal any role of the extracellular enzyme in pathogenesis, unless all genes encoding functionally redundant enzymes are disabled. Rogers and coworkers (2000) demonstrated that only by the disruption of functionally redundant PL would PLA and PLB from N. haematococca give pathogenicity reduction. Addressing a similar question as to why most reports on the disruption of a single or a combination of CWDEs failed to show any reduction in pathogenesis, Tonukari and coworkers (2000) have simultaneously affected a wider range of CWDEs. Because the production of most CWDEs of plant-pathogenic fungi is under catabolite repression, they disrupted the C. carbonum SNF1 gene (encoding a protein kinase), which is required to down regulate glucoserepressed genes, and found this to reduce fungal pathogenicity on maize (Tonukari et al. 2000). In the SNF1 mutant, glucoserepressed genes such as CWDEs remain repressed, supplying a correlation between the reductions of several CWDEs and expression with virulence reduction (Tonukari et al. 2000). This approach was fruitful, yet it did not allow us to distinguish between the contributions of each of the enzymes to pathogenicity.

We obtained gene knockouts of pelB at a reasonable frequency in $C$. gloeosporioides when we used a doublecrossover integration rather than a single-crossover integration. Gene disruption in the fungus $C$. gloeosporioides has been reported to occur mainly by double-crossover homologous recombination (Rikkerink et al 1994), although Bowen et al. (1995) obtained mutants of pectin lyase A with both strategies. A double-crossover homologous recombination is used most commonly for gene disruption in fungi (Garcia-Maceira et al. 2000; Shieh et al. 1997; Van Kan et al. 1997), and our analyses with PCR and Southern blotting showed that the pelB gene was disrupted successfully in $C$. gloeosporioides by this approach. Possibly, the ability to obtain gene knockouts with short DNA fragments may be isolate dependant in $C$. gloeosporioides (Bowen et al. 1995). C. gloeosporioides pelB recently was found not to be catabolite repressed by glucose (N. Drori and D. Prusky, unpublished). This is similar to two other constitutively expressed enzymes shown to be involved in plant pathogenicity (Shieh et al. 1997; ten Have et al. 1998), although the significance of the constitutive expression is not yet known.
The $C$. gloeosporioides pelB mutant grown on pectin medium showed $25 \%$ lower PNL activity and higher PG activity than the wild-type strain. These somewhat unexpected results are best interpreted as indicating that the loss of PLB by the fungus alters the spectrum of pectin degradation products exposed to the fungus and thereby influences the induction of other enzymes. In addition, the pelB mutation may affect the production of pectin oligomers in the infected host, thus influencing host defense mechanisms, as proposed by ten Have et al. (1998). Such oligouronides previously were found to elicit a broad range of rapid responses in plant hosts, including extracellular alkalization, ion efflux across the plasma membrane, and an increased level of oxidative burst (Cote and Hahn 1994; John et al. 1997; Legendre et al. 1993; Wegener et al. 1996). In avocado fruits, it has been reported recently that C. gloeosporioides develops infection hyphae and induces an oxidative burst that leads to the activation of the phenylpropanoid pathway (Beno-Moualem and Prusky 2000). Additionally, a challenge inoculation of intact avocado fruit with the reduced pathogenicity strain of Colletotrichum magna (path1) delayed in PL secretion enhanced PAL activity and other phenylpropanoid biosynthetic enzymes, which in turn increased the flavonoid epicatechin concentration. Epicatechin is an antioxidant that inhibits the decline of the natural antifungal diene affecting avocado fruit resistance to $C$. gloeosporioides attack (Prusky et al. 1994; Wattad et al. 1995). PAL has been described previously as an enzyme in the avocado fruit that is highly correlated to the production of epicatechinmediated fruit resistance (Ardi et al. 1998; Prusky et al. 1994; Prusky et al. 1996). The current results clearly show the sig-

Table 1. Growth rate in vitro of Colletotrichum gloeosporioides pectate lyase B (pelB) mutants on pectin, Na polypectate, and glucose as the sole carbon source ${ }^{\mathrm{a}}$

\begin{tabular}{llcl}
\hline Media & Isolate & $\begin{array}{c}\text { Growth rate } \\
\text { (pH 3.8) }\end{array}$ & $\begin{array}{c}\text { Growth rate } \\
\text { (pH 6.0) }\end{array}$ \\
\hline Glucose & Gg-14 & 13.8 & 12.6 \\
& GD-63 & $13.9(\mathrm{~N})$ & $12.5(\mathrm{~N})$ \\
& GD-14 & $13.1(\mathrm{~N})$ & $12.9(\mathrm{~N})$ \\
& GD-23 & $13.8(\mathrm{~N})$ & $12.4(\mathrm{~N})$ \\
Na polypectate & $13.8(\mathrm{~N})$ & $12.5(\mathrm{~N})$ \\
& GD-29 & 10.7 & 8.5 \\
& Gg-14 & $10.7(\mathrm{~N})$ & $8.5(\mathrm{~N})$ \\
& GD-63 & $11.0(\mathrm{~N})$ & $8.6(\mathrm{~N})$ \\
& GD-14 & $10.4(\mathrm{~N})$ & $8.5(\mathrm{~N})$ \\
& GD-29 & $11.4(\mathrm{~N})$ & $8.2(\mathrm{~N})$ \\
& Gg-14 & 12.7 & 12.8 \\
& GD-63 & $12.8(\mathrm{~N})$ & $12.6(\mathrm{~N})$ \\
& GD-14 & $13.3(\mathrm{~N})$ & $11.0(\mathrm{~S})$ \\
& GD-23 & $12.7(\mathrm{~N})$ & $10.8(\mathrm{~S})$ \\
& GD-29 & $12.5(\mathrm{~N})$ & $11.4(\mathrm{~S})$ \\
\hline
\end{tabular}

${ }^{a}$ Numbers represent the average growth rate calculated from the linear formula, over 4 days (colony diameter in millimeter per day), of pelB mutants GD-14, GD-23, GD-29 and the hygromycin-resistant, undisrupted isolate GD-63 on pectin, $\mathrm{Na}$ polypectate, or glucose media plates at $\mathrm{pH} 3.8$ or 6.0 . Growth rate of each isolate in each medium was compared to the wild-type $C$. gloeosporioides isolate $\mathrm{Cg}-14$ on the same medium. Statistical analysis was performed by repeated measurement type analysis of variance, followed by partition of the time sum of squares into linear and deviation from linear parts. The significance of the differences between the pace of the isolates and their respective control $(\mathrm{Cg}-14)$ also is indicated. $\mathrm{S}=$ significant $(P<0.01) ; \mathrm{N}=$ not significant $(P>0.05)$. 
nificantly higher PAL activity and antifungal diene levels induced by pelB mutants inoculated on the avocado pericarp, thus drawing the scenario that pelB mutants may have affected the resistance mechanisms in the avocado as it did in other reduced pathogenicity mutants (Prusky et al. 1994). A similar mechanism was suggested for PG-inhibiting proteins produced by plants to allow prolonged induction of the plant defense by the altered activity of fungus-PG products of the cell wall-bound pectin (Benhamou 1996).

\section{MATERIALS AND METHODS}

Fungal isolate, avocado fruit, media, and growth conditions. Isolate Cg-14 of C. gloeosporioides (Penz.) Penz. \& Sacc., a pathogen of avocado fruits (Persea americana Mill cv. drymifolia [Schidl. And Cham.] S. F. Blake "Fuerte") was maintained in $10 \mathrm{mM}$ Na-phosphate buffer (pH 7.2) and $40 \%$ glycerol at $-80^{\circ} \mathrm{C}$. Three-week-old conidia were harvested from Mathur's medium $\left(\mathrm{M}_{3} \mathrm{~S}\right)$ plates $(\mathrm{Tu}$ 1985) and used for culture and/or fruit inoculation. For detection of pectolytic enzyme secretion, conidia $\left(1 \times 10^{6}\right.$ conidia per $\left.\mathrm{ml}\right)$ were inoculated into a 250-ml Erlenmeyer flask containing $100 \mathrm{ml}$ of pectolytic enzyme-inducing media (PEIM) consisting of minimal media (per liter: $5 \mathrm{~g}$ of $\mathrm{KNO}_{3} ; 4 \mathrm{~g}$ of $\mathrm{KH}_{2} \mathrm{PO}_{4} ; 2 \mathrm{~g}$ of $\mathrm{MgSO}_{4} 7 \mathrm{H}_{2} \mathrm{O} ; 0.3 \mathrm{~g}$ of $\mathrm{CaCl}_{2} 7 \mathrm{H}_{2} 0$; and $10 \mathrm{mg}$ of $\mathrm{FeCl}_{3}$ ), $\mathrm{pH}$ 3.8, supplemented with $5 \mathrm{~g}$ of Na polypectate and $5 \mathrm{~g}$ of pectin (Sigma, St. Louis, MO, U.S.A.) as the sole carbon source (Prusky et al. 1989). In vitro growth rate on pectic polymers was estimated on minimal media supplemented with $10 \mathrm{~g}$ of citrus pectin per liter, polygalacturonic acid-Na or glucose (Sigma), and $30 \mathrm{~g}$ of Bacto agar (Difco Laboratories, Detroit, MI, U.S.A.) per liter. Each medium was adjusted to $\mathrm{pH} 3.8$ (a level at which $C$. gloeosporioides did not secrete PLB, although PG was secreted) or 6.0 (a level at which PLB was secreted), with $\mathrm{HCl}$ or $\mathrm{NaOH}$, respectively (Yakoby et al. $2000 \mathrm{~b}$ ). All isolates were inoculated onto three plates of each medium by placing a 2-mm agar cube from the edge of a 7day-old growing colony on $\mathrm{M}_{3} \mathrm{~S}$ plates, at the center of each plate, at $26^{\circ} \mathrm{C}$. Colony diameter was measured daily and expressed in millimeters.

\section{Vector construction and transformation.}

All plasmids were electroporated with a Gene Pulser II (Bio-Rad Laboratories, Hercules, CA, U.S.A.) into DH-5 $\alpha$ competent cells, prepared according to the manufacturer's recommendations, and grown on Luria-Bertani media (Sambrook et al. 1989) supplemented with $100 \mu \mathrm{g}$ of ampicillin per $\mathrm{ml}$ at $37^{\circ} \mathrm{C}$ for $15 \mathrm{~h}$ (Sambrook et al. 1989). Plasmids were extracted with Wizard Plus SV Minipreps (Promega, Madison, WI, U.S.A.).

pPEL1.1 containing the 4.1-kb pelB clone in pGEM-7Z (Promega) was used to construct the homologous recombination vector by site-directed mutagenesis. The $\mathrm{XbaI}$ restriction site from the multicloning site of the plasmid was blunted by restriction with $\mathrm{XbaI}$, followed by Klenow fragment filling (Promega) to generate p1.14. Thereafter, p1.14 was subjected to site-directed mutagenesis for the insertion of a $\mathrm{XbaI}$ site at 240 bp after the ATG start codon by inserting adenine (bold and underlined). The two primers used were 5'-GCCGCCACCTCTAGACGAGAAGGCCG- $3^{\prime}$ as forward primer and 5'-CGGCCTTCTCGTCTAGAGGTGGCGGC-3' as reverse primer. The reaction was performed with $P f u$ DNA polymerase (Promega) with a polymerase chain reaction (PCR) Tgradient device (Biometra, Gottingen, Germany) at the following cycles: $95^{\circ} \mathrm{C}$ for $3 \mathrm{~min}$, followed by 18 cycles of $95^{\circ} \mathrm{C}$ for $30 \mathrm{~s}, 55^{\circ} \mathrm{C}$ for $1 \mathrm{~min}, 68^{\circ} \mathrm{C}$ for $12 \mathrm{~min}$, and one cycle of $68^{\circ} \mathrm{C}$ for $14 \mathrm{~min}$. PCR products were digested with DpnI (Promega) for $1 \mathrm{~h}$ and thereafter electrophorated into DH-5 $\alpha$. A single colony was used to obtain pSDM-1, which was restricted with $X b a \mathrm{I}$ and blunted with a Klenow fragment. The 2.13-kb $h p h B$ gene was restricted from pHA-1.3 (Redman and Rodriguez 1994) with HindIII and XbaI blunted with Klenow fragment and subjected to ligation (Promega) for $24 \mathrm{~h}$. Products were transformed to $\mathrm{DH}-5 \alpha$, generating the $9.23-\mathrm{kb}$ transformation vector pGD-4, which had one $X b a \mathrm{I}$ restriction site between the $p e l \mathrm{~B}$ and $h p h B$ genes that were not blunted previously (Fig. 1A).

For fungus transformation, 4-day-old mycelia growing from $1 \times 10^{6}$ conidia $\left(22^{\circ} \mathrm{C}\right.$ in $250 \mathrm{ml}$ of $\left.\mathrm{M}_{3} \mathrm{~S}\right)$ were harvested and 3 $\mathrm{g}$ were digested with $2 \mathrm{mg}$ of Novozyme 234 (Calbiochem, La Jolla, CA) $50 \mathrm{U}$ of $\beta$-glucuronidase (Sigma) per $\mathrm{ml}$ in order to

Table 2. Decay development on avocado fruit by Colletotrichum gloeosporioides pectate lyase B (pelB) mutants ${ }^{\mathrm{a}}$

\begin{tabular}{|c|c|c|c|c|c|c|c|c|c|}
\hline \multirow[b]{2}{*}{ Isolate } & \multirow[b]{2}{*}{ DASI $^{\mathbf{a}}$} & \multicolumn{2}{|c|}{ Experiment 1} & \multicolumn{2}{|c|}{ Experiment 2} & \multicolumn{2}{|c|}{ Experiment 3} & \multicolumn{2}{|c|}{ Experiment 4} \\
\hline & & Cg-14 & Mutant & Cg-14 & Mutant & Cg-14 & Mutant & Cg-14 & Mutant \\
\hline \multirow[t]{5}{*}{ GD-14 } & 1 & 1.26 & 1.26 & 1.96 & 0.27 & 0.53 & 0.13 & -- & -- \\
\hline & 2 & 3.69 & 3.29 & 3.7 & 1.46 & 2.08 & 0.63 & -- & -- \\
\hline & 3 & 5.43 & 5.07 & 6.5 & 3.78 & 4.25 & 2.17 & -- & -- \\
\hline & 4 & 9.92 & 8.75 & 13.7 & 8.68 & 10.0 & 6.04 & -- & -- \\
\hline & & \multicolumn{2}{|c|}{$p=0.51 ; \mathrm{GR}=9.5 \%$} & \multicolumn{2}{|c|}{$p=0.04 ; \mathrm{GR}=45 \%$} & \multicolumn{2}{|c|}{$p=0.008 ; \mathrm{GR}=47 \%$} & & \\
\hline \multirow[t]{6}{*}{ GD-23 } & 1 & 0.54 & 0.33 & 1.6 & 0.97 & 0.9 & 0.53 & 0.27 & 0.01 \\
\hline & 2 & 4.32 & 2.88 & 3.78 & 2.54 & 2.6 & 2.0 & 2.72 & 0.68 \\
\hline & 3 & 7.32 & 5.06 & 6.78 & 4.34 & 5.27 & 3.95 & 3.77 & 1.0 \\
\hline & 4 & 11.46 & 7.19 & 10.8 & 6.96 & 14.6 & 10.86 & 7.6 & 4.2 \\
\hline & 5 & 16.28 & 10.23 & 14.1 & 10.2 & -- & -- & 17.8 & 9.7 \\
\hline & & \multicolumn{2}{|c|}{$p=0.05 ; \mathrm{GR}=36 \%$} & \multicolumn{2}{|c|}{$p=0.02 ; \mathrm{GR}=33 \%$} & \multicolumn{2}{|c|}{$p=0.05 ; \mathrm{GR}=26 \%$} & \multicolumn{2}{|c|}{$p=0.03 ; \mathrm{GR}=51 \%$} \\
\hline
\end{tabular}

a Decay development (colony diameter in millimeters) of pelB mutants GD-14, GD-23, and wild-type C. gloeosporioides isolate Cg-14 on avocado fruits cv. Fuerte, 4 days after symptom initiation (DASI). Fruits were inoculated on both sides of the longitudinal axis of the fruit with conidia of $C$. gloeosporioides isolate $\mathrm{Cg}-14$ or the pelB disrupted isolates with two repetitions of each isolate on the same fruit. The first three experiments were carried out with 18 repetitions (fruits), and the fourth experiment with 11 repetitions (fruits). Significance was calculated from a comparison of the daily decay diameters of the pelB disrupted mutants and the wild-type, which were analyzed statistically by repeated measurement type analysis of variance $(p)$. Growth reduction (GR) was calculated as the sum of the daily values of decay development of the pelB disrupted mutants from the wild type during each experiment. 
obtain fungal protoplasts (Redman and Rodriguez 1994). Protoplasts were transformed with $1 \mu \mathrm{g}$ of pGD-4, followed by a 24-h incubation at $22^{\circ} \mathrm{C}$, and selected by spooling onto media containing $100 \mu \mathrm{g}$ of hygromycin plates per ml (Redman and Rodriguez 1994). Hygromycin-resistant colonies were collected 4 to 8 days later and transferred to new hygromycin plates. Colonies were transferred to $\mathrm{M}_{3} \mathrm{~S}$ plates to enhance sporulation, and a single conidium culture was obtained following conidia inoculation on hygromycin.

\section{PCR screening and Southern analysis.}

Fungal colonies were transferred to new $\mathrm{M}_{3} \mathrm{~S}$ plates and grown for $24 \mathrm{~h}$ at $26^{\circ} \mathrm{C}$. A sample of growing hyphae from the edge of the colony was subjected to PCR technology: $5^{\prime}$-GCTCGAAACTAGTCAAGATGAAG- $3^{\prime}$ as forward primer and 5'-TACATGAATTCTGTACTTCTCAG-3' as reverse primer. The forward primer included the start codon (ATG $=$ bold and italics) of the pelB gene and the reverse primer was $115 \mathrm{bp}$ downstream from the stop codon. A 1.12-kb DNA fragment was obtained following PCR amplification with $3 \mathrm{U}$ of Bio-XACT DNA polymerase (Bioline, London, U.K.), in the presence of $2 \mathrm{mM} \mathrm{MgCl}_{2}$, with the following cycles: one cycle of $95^{\circ} \mathrm{C}$ for $3 \mathrm{~min}, 30$ cycles of $95^{\circ} \mathrm{C}$ for $30 \mathrm{~s}, 55^{\circ} \mathrm{C}$ for $1 \mathrm{~min}$, $72^{\circ} \mathrm{C}$ for $2 \mathrm{~min}$, and one cycle of $72^{\circ} \mathrm{C}$ for $10 \mathrm{~min}$. PLB disrupted mutants predicted to generate a $3.33-\mathrm{kb}$ band but not the 1.12-kb band appeared when wild-type Cg-14 DNA was used as a template. When PCR used hyphae tips as a source of DNA, the template did not generate the 3.33-kb fragment, therefore DNA was extracted as described by Rodriguez (1993) from $0.2 \mathrm{~g}$ of dry mycelium, and a 200-ng genomic DNA of each isolate was subjected to another round of PCR under the same conditions.

Fungal DNA $(5 \mu \mathrm{g})$ restricted with $24 \mathrm{U}$ of $\mathrm{XbaI}$ (Promega) for $15 \mathrm{~h}$ at $37^{\circ} \mathrm{C}$ was run on an $0.8 \%$ agarose gel for $4 \mathrm{~h}$ at 50 V. The DNA was blotted onto a HyBond+ nylon membrane (Amersham Pharmacia Biotech, Little Chalfont, Buckinghamshire, U.K.) by capillary method with $20 \times$ SSC $(1 \times$ SSC is $0.15 \mathrm{M} \mathrm{NaCl}$ plus $0.015 \mathrm{M}$ sodium citrate) (Sambrook et al. 1989). All hybridizations were carried out at $65^{\circ} \mathrm{C}$, and membrane washes were conducted with $0.1 \times \mathrm{SSC}$.

\section{Protein extraction and Western analysis.}

Secreted protein was extracted after 4-day growth of $1 \times$ $10^{6}$ C. gloeosporioides conidia in $50 \mathrm{ml}$ of PEIM. The fungus was harvested by centrifugation at $12,000 \mathrm{~g}$ for $10 \mathrm{~min}$, and the clear supernatant was concentrated on a rotavapor (Buchii, Flawil, Switzerland) at $42^{\circ} \mathrm{C}$ to $5 \mathrm{ml}$. The concentrated media was subjected to overnight dialysis against 5 liters of $50 \mathrm{mM}$ Tris- $\mathrm{HCl}, \mathrm{pH} \mathrm{8.5,} \mathrm{and} \mathrm{then} \mathrm{reconcentrated} \mathrm{to} 1 \mathrm{ml}$, as described above. Protein concentration was determined by the BioRad protein assay with a standard dilution of bovine serum albumin (Sigma).

Each $5 \mu \mathrm{g}$ sample was run on a $12.5 \%$ sodium dodecyl sulfate-polyacrylamide gel (Mini-Protean II, BioRad) for $1 \mathrm{~h}$ at $150 \mathrm{~V}$ constant voltage and Western blot analysis was performed with PLB antibodies (Wattad et al. 1995).

\section{PL, pectin lyase (PNL), and PG activities.}

PL, PNL, and PG activities were assayed as described by Collmer et al. (1988). PL and PNL activities were conducted with $5 \mu \mathrm{g}$ of protein, which was on the linear portion of the curve for $5 \mathrm{~min}$ in a spectrophotometer (Uvikon 820, Kontron, Basel, Switzerland) at $232 \mathrm{~nm}$. PL activity was expressed as the accumulated absorption change of $1 \mu \mathrm{mol}$ of the 4,5unsaturated galacturonide product of $\mathrm{Na}$ polygalacturonate (Sigma) per minute, at $25^{\circ} \mathrm{C}$. PNL activity assay was performed by altering the substrate of PL by deletion of calcium and the substitution of citrus pectin (Sigma) for Na polygalacturonate (Sigma). The molar extinction coefficient for the unsaturated product at $232 \mathrm{~nm}$ is 4,600 per $\mathrm{M}$ per $\mathrm{cm}$. One unit of PL or PNL is $1 \mu \mathrm{mol}$ of 4,5-unsaturated products from $\mathrm{Na}$ polypectate or pectin, respectively, for 1 min under the conditions of the assay. PG activity was assayed by monitoring the release of reducing groups from $\mathrm{Na}$ polygalacturonate. The substrate stock solution was prepared by adding $10 \mathrm{ml}$ of $0.6 \mathrm{M} \mathrm{NaCl}$ with rapid mixing into $40 \mathrm{ml}$ of solution containing $75 \mathrm{mM} \mathrm{Na}$ acetate, $\mathrm{pH} 5.3 ; 7.5 \mathrm{mM}$ EDTA; and 0.3\% (wt/vol) polygalacturonic acid. Reaction mixtures consisted of $0.5 \mathrm{ml}$ of substrate solution and $2 \mu \mathrm{g}$ of concentrated media, followed by incubation for $10 \mathrm{~min}$ at $25^{\circ} \mathrm{C}$. Reactions were terminated by adding $0.5 \mathrm{ml}$ of copper reagent followed by a 10 -min incubation in a boiling water bath. The tubes were cooled to room temperature, and $1 \mathrm{ml}$ of arsenomolybdate was added (Nelson 1944). The absorbance was read at $500 \mathrm{~nm}$. PG activity was calculated in comparison to a D-galacturonic acid standard curve to determine enzyme activity. Units are expressed in nmol of $\mathrm{D}$-galacturonic acid per minute.

\section{Pathogenicity assay on avocado fruits and PAL induction.}

Avocado fruits (cv. Fuerte) were inoculated on both sides of the longitudinal axis of the fruit with $10 \mu \mathrm{l}$ of conidia $\left(1 \times 10^{6}\right.$ conidia per $\mathrm{ml}$ ) of $C$. gloeosporioides, isolate $\mathrm{Cg}-14$, or the pelB disrupted isolates, with two repetitions of each isolate on the same fruit. Similar inoculations were performed on 18 fruits for three experiments and 11 fruits for the fourth experiment. Decay development was monitored in each experiment four times during fruit storage at $20^{\circ} \mathrm{C}$ by measuring lesion diameter. Significance was calculated from the comparison of the daily diameters of decay of the pelB disrupted

Table 3. Phenylalanine ammonia lyase (PAL) activity inducted by $\mathrm{Col}$ letotrichum gloeosporioides pectate lyase B (pelB) mutants on avocado pericarp cv. Fuerte ${ }^{\mathrm{a}}$

\begin{tabular}{lc}
\hline Treatment & $\mathbf{2 4 ~ h}$ \\
\hline Control & $3.55 \pm 0.23(\mathrm{~A})$ \\
Cg-14 & $4.13 \pm 0.68(\mathrm{~A})$ \\
GD-14 & $7.20 \pm 0.62(\mathrm{~B})$ \\
Control & $2.97 \pm 0.60(\mathrm{~A})$ \\
Cg-14 & $4.08 \pm 0.35(\mathrm{~B})$ \\
GD-23 & $5.59 \pm 1.03(\mathrm{C})$ \\
Control & $3.48 \pm 0.35(\mathrm{~A})$ \\
Cg-14 & $3.92 \pm 0.27(\mathrm{~A})$ \\
GD-63 & $4.17 \pm 0.43(\mathrm{~A})$ \\
\hline
\end{tabular}

${ }^{a}$ PAL activity ( $\mu \mathrm{mol}$ of cinnamic acid per mg protein per $\mathrm{h}$ ) on a slice of avocado pericarp induced by pelB mutants GD-14 and GD-23, wildtype $C$. gloeosporioides (Cg-14), and water (control). All treatments for each isolate were carried out on the same avocado fruit for each experiment. Results are the average of one representative experiment out of three independent experiments. Data is the average of three repetitions and the standard deviation of one experiment. Significance between treatments was calculated by analysis of variance. Significance calculated from the control $(P<0.05)$ within each experiment: $\mathrm{B}=$ significant from $\mathrm{A} ; \mathrm{C}=$ significant from $\mathrm{A}$ and from $\mathrm{B}$. 
mutants and the wild type. Statistical analysis was carried out by repeated measurement type analysis of variance, where each fruit represents a block in every experiment. Growth reduction is expressed as a percentage and was calculated as the sum of the daily values of decay development of the pelB disrupted mutants versus the wild type. Conidia germination was estimated on a glass slide under a light microscope and found to be 70 to $90 \%$ for wild-type $\mathrm{Cg}-14$ and the pelB disrupted isolates.

The evaluation of PAL induction by the pelB mutants was performed on avocado pericarp slices (5 $\mathrm{g}$ at 2- to 3-mm thick) by inoculation of the external side with $10 \mu$ of conidia suspension $\left(1 \times 10^{6}\right.$ conidia per $\left.\mathrm{ml}\right)$ at four spots along the longitudinal axis of the cut piece. Inoculated and noninoculated slices were taken from the same fruit for each experiment to prevent physiological differences between the fruits. Pericarp samples were harvested $24 \mathrm{~h}$ after inoculation (BenoMoualem and Prusky 2000) by blending in $50 \mathrm{ml}$ of cold acetone $\left(-20^{\circ} \mathrm{C}\right)$. The powder retained on Whatman no. 1 paper (Kent, U.K.) was blended twice more in cold acetone before drying and storing in $-20^{\circ} \mathrm{C}$. PAL was extracted from $100 \mathrm{mg}$ of powder by stirring for $2 \mathrm{~h}$ at $4^{\circ} \mathrm{C}$ with $5 \mathrm{ml}$ of $0.1 \mathrm{M}$ sodium borate buffer, $\mathrm{pH} 8.8$. The extract was centrifuged at $10,000 \mathrm{~g}$ for $20 \mathrm{~min}$ at $4^{\circ} \mathrm{C}$, and the supernatant was used as an enzyme source. The reaction mixture consisted of $10 \mathrm{mM} \mathrm{L}$ phenylalanine (Sigma), 0.1 M borate buffer ( $\mathrm{pH} \mathrm{8.8),} \mathrm{and} 1.5$ $\mathrm{ml}$ of enzyme extract in a final volume of $5 \mathrm{ml}$. The reaction was incubated for $1 \mathrm{~h}$ at $37^{\circ} \mathrm{C}$ and terminated by adding $0.1 \mathrm{ml}$ of $5 \mathrm{~N} \mathrm{HCl}$. The product, cinnamic acid, was extracted into 7 $\mathrm{ml}$ of diethyl ether and quantified at $269 \mathrm{~nm}$ (Lisker et al. 1983).

\section{Antifungal diene extraction.}

A 10-g sample of avocado pericarp (2- to 3-mm thick) was homogenized in $95 \%$ ethanol in an Omni-Mixer (Sorvall, DuPont Company, Newtown, CT, U.S.A.) at full speed for $3 \mathrm{~min}$. The ethanol extract was dried in a rotary evaporator at $40^{\circ} \mathrm{C}$, redissolved in $10 \mathrm{ml}$ of distilled water, and the organic phase was extracted by fractionation with dichloromethane. Following two extractions, the organic phases were pooled, dried with anhydrous $\mathrm{MgSO}_{4}$ (Riedel-deHaen, Seelze, Germany), and evaporated to dryness. Samples were redissolved in $1 \mathrm{ml}$ of ethanol AR (Bio Lab, Jerusalem, Israel) and analyzed by high-pressure liquid chromatography (Prusky et al. 1994). The average values of three separate extractions are presented.

\section{ACKNOWLEDGMENTS}

We thank D. Genizi, Department of Statistics, ARO, Volcani Center, Israel, for statistical analysis. This work was supported by research grants IS-2686-96 to D. Prusky and N. T. Keen from BARD, the United States-Binational Agricultural Research and Development Fund, and to D. Prusky by the German-Israel Agricultural Research Agreement (GIARA) for the Benefit of the Third World and the U.S.-Israel Cooperative Development Research (CDR) program. N. Yakoby was granted personal scholarships from the Israel Fruit Marketing Board-Ministry of Agriculture \& Rural Development and the Association of Trustees and Friends of the Agricultural Research Organization.

\section{LITERATURE CITED}

Annis, S. L., and Goodwin, P. H. 1997. Recent advances in the molecular genetics of plant cell wall-degrading enzymes produced by plant pathogenic fungi. Eur. J. Plant Pathol. 103:1-14.

Ardi, R., Kobiler, I., Keen, N. T., and Prusky, D. 1998. Involvement of epicatechin biosynthesis in the resistance of avocado fruits to postharvest decay. Physiol. Mol. Plant Pathol. 53:269-285.

Benhamou, N. 1996. Elicitor-induced plant defence pathways. Trends Plant Sci. 1:233-240.

Beno-Moualem, D., and Prusky, D. 2000. Early events during quiescent infection development by Colletotrichum gloeosporioides in unripe avocado fruits. Phytopathology 90:553-559.

Bowen, J. K., Templeton, M. D., Sharrock, R. K., Crowhurst, N. R., and Rikkerink, E. H. 1995. Gene inactivation in the plant pathogen Glomerella cingulata: Three strategies for the disruption of the pectin lyase gene pnlA. Mol. Gen. Genet. 246:196-205.

Bowyer, P., Clarke, B. R., Lunness, P., Daniels, M. J., and Osbourne, A. E. 1995. Host range of a plant pathogenic fungus determined by a saponin detoxification enzyme. Science 267:371-374.

Collmer, A., and Keen, N. T. 1986. The role of pectic enzymes in plant pathogenesis. Ann. Rev. Phytopathol. 24:383-409.

Collmer, A., Ried, J. L., and Mount, S. M. 1988. Assay methods for pectic enzymes. Methods Enzymol. 161:329-335.

Cote, F., and Hahn, M. G. 1994. Oligosaccharines: Structure and signal transduction. Plant Mol. Biol. 26:1379-1411.

Garcia-Maceira, F. I., Di Pietro, A., and Roncero, M. I. G. 2000. Cloning and disruption of pgx4 encoding an in planta expressed exopolygalacturonase from Fusarium oxysporum. Mol. Plant-Microbe Interact. 13:359-365.

Gou, W., Gonzalez-Candelas, L., and Kolattukudy, P. E. 1995. Cloning of a novel pectate lyase gene pelB from Fusarium solani f. sp. pisi (Nectria haematococca, mating type VI) and characterization of the gene product expressed in Pichia pastoris. J. Bacteriol. 177:70707077.

Hamer, J. E., and Holden, D. W. 1997. Linking approaches in the study of fungal pathogenesis: A commentary. Fungal Genet. Biol. 21:11-16.

John, M., Rohrig, H., Schmidt, J., Walden, R., and Schell, J. 1997. Cell signaling by oligosaccharides. Trends Plant Sci. 2:111-115.

Kelemu, S., and Collmer, A. 1993. Erwinia chrysanthemi EC16 produces a second set of plant inducible pectate lyase isozymes. Appl. Environ. Microbiol. 59:1756-1761.

Legendre, L., Rueter, S., Heinstein, P. F., and Low, P. S. 1993. Characterization of the oligogalacturonate-induced oxidative burst in cultured soybean (Glycine max) cells. Plant Physiol. 102:233-240.

Lisker, N., Cohen, L., Chalutz, E., and Fuchs, Y. 1983. Fungal infections suppress ethylene induced phenylalanine ammonia lyase activity in grapefruit. Physiol. Plant Pathol. 22:331-338.

Nelson, N. 1944. A photometric adaptation of the Somogyi method for the determination of glucose. J. Biol. Chem. 153:375-380.

Ortega, J. 1996. Pectolytic enzymes produced by the phytopathogenic fungus Colletotrichum gloeosporioides. Tex. J. Sci. 48:123-128.

Prusky, D. 1996. Quiescent infections by postharvest pathogens. Annu. Rev. Phytopathol. 34:413-434.

Prusky, D., Gold, S., and Keen, N. T. 1989. Purification and characterization of an endopolygalacturonase produced by Colletotrichum gloeosporioides. Physiol. Mol. Plant Pathol. 35:121-133.

Prusky, D., Freeman, S., Rodriguez, R. J., and Keen, N. T. 1994. A nonpathogenic mutant strain of Colletotrichum magna induces resistance to $C$. gloeosporioides in avocado fruits. Mol. Plant-Microbe Interact. 7:326-333.

Prusky, D., Hamdan, H., Ardi, R., and Keen, N. T. 1996. Induction of biosynthesis of epicatechin in avocado cell suspension treated with enriched $\mathrm{CO}_{2}$ atmosphere. Physiol. Mol. Plant Pathol. 48:171-178.

Redman, S. R., and Rodriguez, R. J. 1994. Factors affecting the efficient transformation of Colletotrichum species. Exp. Mycol. 18:230-246.

Ried, J. L., and Collmer, A. 1988. Construction and characterization of an Erwinia chrysanthemi mutant with directed deletions in all of the pectate lyase structural genes. Mol. Plant-Microbe Interact. 1:32-38.

Rikkerink, E. H., Solon, S. L., Crowhurst, R. N., and Templeton, M. D. 1994. Integration of vectors by homologous recombination in the plant pathogen Glomerella cingulata. Curr. Genet. 25:202-208.

Rodriguez, R. J. 1993. Polyphosphate present in DNA preparations from filamentous fungal species of Colletotrichum inhibits restriction endonucleases and other enzymes. Anal. Biochem. 209:291-297.

Rogers, L. M., Kim, Y., Guo, W., Gonzales-Candelas, L., Li, D., and Kolattukudy, P. E. 2000. Requirement of either a host or pectin-induced pectate lyase for infection of Pisum sativum by Nectria haematococca. Proc. 
Natl. Acad. Sci. USA 97:9813-9818.

Rothstein, R. J. 1983. One-step gene disruption in yeast. Methods Enzymol. 101:202-211.

Sambrook, J., Fritsch, E. F., and Maniatis, T. A. 1989. Molecular Cloning: A Laboratory Manual, 2nd ed. Cold Spring Harbor Laboratory, Cold Spring Harbor, NY, U.S.A.

Scott-Craig, J. S., Cheng, Y. Q., Cervone, F., De Lorenzo, G., Pitkin, J. W., and Walton, J. D. 1998. Targeted mutant of Cochliobolus carbonum lacking the two major extracellular polygalacturonases. Appl. Environ. Microbiol. 64:1497-1503.

Sheng-Cheng, W., Kyung-Sik, H., Darvill, G. A., and Albersheim, P. 1997 . Deletion of the two endo- $\beta-1,4$-xylanase genes reveals additional isozymes secreted by the rice blast fungus. Mol. Plant-Microbe Interact. 10:700-708.

Shieh, M., Brown, R. L., Whitehead, M. P., Carey, J. W., Cotty, P. J., Cleveland, T. E., and Dean, R. A. 1997. Molecular genetic evidence for the involvement of a specific polygalacturonase, $\mathrm{P} 2 \mathrm{c}$, in the invasion of Aspergillus flavus in cotton balls. Appl. Environ. Microbiol. 63:3548-3552.

Shih, J., Wei, Y., and Goodwin, P. H. 2000. A comparison of the pectate lyase genes, pel-1 and pel-2, of Colletotrichum gloeosporioides $\mathrm{f}$. $\mathrm{sp}$. malvae and the relationship between their expression in culture and during necrotrophic infection. Gene 243:139-150.

Shortle, D., Haber, J. F., and Botstein, D. 1982. Lethal disruption of the yeast actin gene by integrative DNA transformation. Science 217:371373.

Templeton, M. D., Keith, K. R., Bowen, J. K., Crowhurst, R. N., and Rikkerink, E. H. 1994. The pectin lyase-encoding gene ( $p n l)$ family from Glomerella cingulata: Characterization of pnlA and its expression in yeast. Gene 142:141-146.

ten Have, A., Mulder, W., Visser, J., and Van Kan, J. A. L. 1998. The endopolygalacturonase gene Bcpg1 is required for full virulence of Botrytis cinerea. Mol. Plant-Microbe Interact. 11:1009-1016.

Tonukari, N. J., Scott-Craig, J. S., and Walton, J. D. 2000. The Coch- liobolus carbonum SNF1 gene is required for cell wall-degrading enzyme expression and virulence on maize. Plant Cell 12:237-248.

Tu, J. C. 1985. An improved Mathur's medium for growth, sporulation and germination of spores of Colletotrichum lindemuthianum. Microbiosis 44:87-93.

Van Kan, J. A. L., Van't Klooster, J. W., Wagemakers, C. A. M., Dees, D. C. T., and Van der Vlugt-Bergmans, C. J. B. 1997. Cutinase A of Botrytis cinerea is expressed, but not essential, during penetration of gerbera and tomato. Mol. Plant-Microbe Interact. 10:30-38.

Walton, J. D. 1994. Deconstructing the cell wall. Plant Physiol. 104:1113-1118.

Wattad, C., Dinoor, A., and Prusky, D. 1994. Purification of pectate lyase produced by Colletotrichum gloeosporioides and its inhibition by epicatechin: A possible factor involved in the resistance of unripe avocado fruits to anthracnose. Mol. Plant-Microbe Interact. 7:293297.

Wattad, C., Freeman, S., Dinoor, A., and Prusky, D. 1995. A nonpathogenic mutant of Colletotrichum magna is deficient in extracellular secretion of pectate lyase. Mol. Plant-Microbe Interact. 8:621-626.

Wattad, C., Kobiler, D., Dinoor, A., and Prusky, D. 1997. Pectate lyase of Colletotrichum gloeosporioides attacking avocado fruits: cDNA cloning and involvement in pathogenicity. Physiol. Mol. Plant Pathol. 50:197-212.

Wegener, C., Bartling, S., Olsen, O., Weber, J., and Von Wettstein, D. 1996. Pectate lyase in transgenic potatoes confers pre-activation of defence against Erwinia carotovora. Physiol. Mol. Plant Pathol. 49:359-376.

Yakoby, N., Freeman, S., Dinoor, A., Keen, N. T., and Prusky, D. 2000a. Expression of pectate lyase from Colletotrichum gloeosporioides in C. magna promotes pathogenicity. Mol. Plant-Microbe Interact. 13:887-891.

Yakoby, N., Kobiler, I., Dinoor, A., and Prusky, D. 2000b. pH regulation of pectate lyase secretion modulates the attack of Colletotrichum gloeosporioides on avocado fruit. Appl. Environ. Microbiol. 66:1026-1030. 